\title{
Sciendo
}

Administration, vol. 68, no. 1 (2020), pp. 27-38

doi: 10.2478/admin-2020-0003

\section{Local government, 2019}

\author{
Fergal O'Leary \\ Institute of Public Administration, Ireland
}

A particularly eventful year for local government, 2019 saw the election of new councils across the country. The issue of directly elected mayors was decided by voters in Cork City, Limerick and Waterford. Besides the political excitement and change of an election year, it was equally hectic on the operational and strategic side. From a climate action plan to a community development strategy, new reports brought new proposals and priorities. Scrutiny of the sector produced a review of the local community development committees (LCDCs), an analysis of social housing acquisitions and, of course, oversight reports. In financial matters, nineteen local authorities varied their local property rate upwards in 2019. As local authorities grapple with the housing crisis, Budget 2020 allocated $€ 2.6$ billion to the housing budget. Thus, the usual ebb and flow of local government continued.

\section{Local elections}

The local and European elections took place on 24 May. A total of 949 city and county councillors were returned to Ireland's 31 councils. The national turnout at the elections was estimated at 50.2 per cent - a 2 per cent drop on 2014's figure (Ó'Riordáin, 2019). Indeed, this continued the downward turnout trend for local elections since 2004 (see Table 1). Over 1,980 candidates stood for election across the country. Of these, 226 women candidates were elected, or 24 per cent 
of all councillors elected (an increase of 3 per cent on the 2014 figure). It should be noted that Ireland still lags behind the EU28 average of 32 per cent for female representation in local politics (National Women's Council, 2019). A total of 53 candidates born outside of Ireland stood in the elections, with 8 securing a council place.

Table 1: Local election turnout, 2004-19

\begin{tabular}{cc}
\hline Year & Turnout $(\%)$ \\
\hline 2004 & 59 \\
2009 & 58 \\
2014 & 52 \\
2019 & 50 \\
\hline
\end{tabular}

Source: Quinlivan (2019).

The electorates in Cork City, Limerick and Waterford were asked for their say in a plebiscite on the matter of directly elected mayors. As an election issue, it arguably failed to capture the public's imagination in the areas concerned. Ultimately, only voters in Limerick City and County Council supported the proposal (see Table 2). The Minister for Housing, Planning and Local Government will proceed with legislation for enabling the election of a mayor in Limerick (Shannon, 2019). Meanwhile, the argument for a directly elected mayor in the capital rumbles on.

Table 2: Directly elected mayors

\begin{tabular}{lccl}
\hline Local authority & Votes for & Votes against & \multicolumn{1}{c}{ Result } \\
\hline Cork City & $33,364(49.3 \%)$ & $34,347(50.7 \%)$ & $\begin{array}{l}\text { Rejected } \\
\text { by 983 votes } \\
\text { Accepted } \\
\text { by 3,549 votes }\end{array}$ \\
$\begin{array}{l}\text { Limerick City } \\
\text { and County Council }\end{array}$ & $38,122(52.4 \%)$ & $34,573(47.6 \%)$ & \\
$\begin{array}{l}\text { Waterford City } \\
\text { and County Council }\end{array}$ & $21,718(49.2 \%)$ & $22,437(50.08 \%)$ & $\begin{array}{l}\text { Rejected } \\
\text { by 719 votes }\end{array}$ \\
\hline
\end{tabular}

Source: Shannon (2019).

On a historical note, April 2019 marked the 120th anniversary of the first local elections held in Ireland. To mark this occasion, a mobile exhibition celebrating the history of Ireland's local government system travelled to local authorities during the year. This special exhibition was compiled and curated by local authority archivists and record managers. 


\section{Housing issues}

Housing remains a key priority for local authorities. Official figures show that by the end of September, the local authorities had built 910 units of social housing and had acquired 1,050 from the market (see Department of Housing, Planning and Local Government, 2019e; Department of Public Expenditure and Reform, 2019). Nearly 13,000 Housing Assistance Payment (HAP) tenancies were provided within this time frame. The level of homelessness continues to be high. According to figures for November, 10,448 people were deemed homeless - comprising adults and children (Department of Housing, Planning and local Government, 2019a). Data for the 2019 summary of social housing assessments showed a small decrease of 4.4 per cent in the numbers of qualified households on the national social housing waiting list, down from 71,858 in 2018 to 68,693 in 2019 (Housing Agency, 2019). October's national budget promised an increase of 11 per cent in funding to improve the supply of affordable and social housing and alleviate homelessness.

In May the Residential Tenancies Act, 2019, was enacted. This legislation sought to better regulate the short-term letting market among other matters. Whilst the new rules around registration, planning permission and time caps were broadly welcomed, questions were raised about the support given to local authorities to help with their enforcement responsibilities.

The housing needs of particular groups were a focus for policymakers in 2019. A policy statement, Housing Options for Our Ageing Population, was issued in February (Department of Housing, Planning and Local Government, 2019b). Local authorities will play a pivotal part in the implementation of the proposed actions to improve housing options in an ageing society. These include reviewing the adaptation grant scheme, working closely with the Health Service Executive and adapting council housing stock.

In July another comprehensive report, Traveller Accommodation Expert Review, was published. Prepared by an expert independent group for the Department of Housing, Planning and Local Government (DHPLG), it examined the delivery of Traveller accommodation. Whilst some local authorities met their delivery targets, others failed. Proposals to reform the local governance structures for Traveller accommodation were set out (Department of Housing, Planning and Local Government, 2019f). 
In its Spending Review series, the Irish Government Economic and Evaluation Service (IGEES) published, in August, a review on social housing acquisitions. The rationale for the acquisition programme was clearly explained, but some local authorities have relied on the programme to meet their social housing delivery targets to a greater extent than others. With house prices rising nationally in recent years, cost efficiency for the Exchequer comes into focus. The majority of acquisitions were below the DHPLG's average cost guidelines, but a portion were above this level. The impact of the local authorities' acquisition programme on the wider housing market was considered. In certain areas, their acquisitions account for over 10 per cent of transactions in the wider market. Greater monitoring of local housing markets, to determine the extent of the local authority impact, needs to take place. The IGEES concluded that further research is required to draw firmer conclusions.

Escalating house prices have meant that affordability has returned as a major challenge for many would-be buyers. The local authorities are set to resume their role in the delivery of affordable housing. Details were provided by local authorities during the year on the development of state-owned lands for such housing. To assist local authorities, additional funds were announced in Budget 2020 for the Serviced Sites Fund and the Housing Activation Fund - both mechanisms designed to accelerate the delivery of affordable units.

\section{Community development}

Community development remains a challenging policy space. A review of LCDCs was published in July. Several operational issues were highlighted by the review process and recommendations put forward. Improving cross-departmental support for the LCDC process on a long-term basis is a priority. In August a five-year strategy for Ireland's community and voluntary sector was published. This promised to strengthen the capacity of local authorities and LCDCs in their developmental efforts (Department of Rural and Community Development, 2019). Of course, adequate funding is crucial to help achieve strategic ambitions. To this end, Budget 2020 allocated an extra $€ 17$ million to the Department of Rural and Community Development. There will be a knock-on effect for local government. Investment will be increased in the LCDC and Public Participation Network structures, the LEADER and SICAP programmes, and public libraries. 


\section{Local enterprise}

In April the fifth anniversary of the establishment of local enterprise offices (LEOs) was celebrated. In their relatively short existence, Ireland's 31 LEOs have created over 18,000 jobs, trained over 140,000 entrepreneurs and business people and grant-aided over 5,000 projects. The LEOs' job-creation impact is growing each year. The latest Performance Indicator Report by the National Oversight and Audit Commission (NOAC, 2019a) showed that the LEOs assisted in the creation of 3,656 whole-time-equivalent jobs in 2018, a 12 per cent year-on-year increase. Indeed, the future of local enterprise support looks bright. In March the Future Jobs Ireland 2019 report was launched. It spoke about the LEOs' work in terms of helping to deliver balanced regional development and diversifying Ireland's enterprise base (Government of Ireland, 2019b). In October the OECD launched a review entitled SME and Entrepreneurship Policy in Ireland. Its recommendations will form the basis of the government's upcoming enterprise strategy that will seek to strengthen the LEOs' role. The results of a $€ 2.5$ million competitive fund were announced in October that will support LEO-led collaborative projects. Uncertainty over a Brexit withdrawal deal and the nature of a future EU-UK trading relationship occupied the minds of many business owners in 2019. In this context, the LEOs offered a comprehensive range of supports to prepare Ireland's small businesses for the UK's exit from the EU. In the event of a no-deal Brexit, the government confirmed that $€ 5$ million would be allocated to a LEO emergency Brexit fund.

\section{Environment}

In April the Department of Culture, Heritage and the Gaeltacht announced additional funding for biodiversity projects. Changes to the application process, made by the department, were designed to give local authorities greater flexibility in terms of how funding was spent. Furthermore, Budget 2020 committed additional support for biodiversity projects and initiatives.

The local authorities' role in tackling the climate crisis will deepen after June's highly publicised launch of the Climate Action Plan 2019 (Government of Ireland, 2019a). In their leadership capacity, local authorities are expected to adopt a climate action charter to help reduce the sector's carbon footprint and promote better public awareness. Legislation will be passed to enable councils to designate 
low- and zero-emission driving zones. Climate action community engagement offices will be piloted. Additionally, the retrofitting of council housing, with minimum BER standards, to improve energy efficiency will continue. The climate action regional offices, which assisted local authorities in the completion of their adaptation strategies, will support many of the actions arising from the plan. In total, local authorities were designated as lead partners in seven actions, and as key stakeholders in a further twenty-two.

Several months later, in October, the climate action charter was signed by the County and City Management Association (CCMA). Local government thereby committed itself to embedding the principles of climate action across its activities. The charter will give renewed impetus to local authority action in this most urgent area.

\section{Tourism}

The report Tourism is Everyone's Business, prepared by the CCMA and the Local Government Management Agency (LGMA), was launched in April. Its figures were impressive and underscore the local authorities' work in this area. Nearly $€ 100$ million was invested by local government in the tourism sector over 2014-18. Local authorities directly operated 260 tourist attractions in 2018 and supported a further 202 privately run attractions. Future investment of $€ 156$ million will fund some 256 new tourist projects across the country. Planned developments include walking trails, blueways and greenways, historical structures, visitor centres, cultural events and improved signage. Indeed, some 300 local authority staff work in tourism development - clearly, a growing area of responsibility.

Tourism's valuable contribution to local economies, especially in rural areas, means that its promotion goes hand in hand with local government's enhanced economic development role. Following on from 2018's memorandum of understanding between the CCMA and Fáilte Ireland, this report reaffirms the collaborative intent of local government and its partners to strategically develop the sector.

\section{Planning}

April saw the establishment of the Office of the Planning Regulator (OPR). This marked a milestone in the evolution of Ireland's planning system. It followed a recommendation of the Mahon Tribunal to transfer planning enforcement powers from the Minister for the 
Environment to an independent regulatory body. Headed by Niall Cussen, the OPR is tasked with scrutinising the forward planning of local authorities and regional assemblies, and zoning decisions. In practice, this means the assessment of over 200 draft plans (development plans, local area plans, regional spatial and economic strategies) and variations on a cyclical basis. By keeping a sharp eye on the country's thirty-one planning authorities, a more consistent and cohesive approach to local and regional plan making is envisaged. A stronger planning system will, in turn, result in better outcomes and help restore public confidence.

In another planning first, a Marine Planning Policy Statement was published in November by the DHPLG (2019d). In comparison to land planning, Ireland's marine planning system is less mature. In setting out a programme of reform, the statement broadly sketched out the marine planning process, a future vision, accompanying principles and high-level priorities. Many local authorities have extensive responsibilities in marine planning. This statement was published alongside a draft of Ireland's first National Marine Planning Framework, due to be finalised in 2020. Reform of marine planning promises to bring into operation a modern and integrated system.

\section{Finance}

Total expenditure by local authorities for 2019 was budgeted at $€ 8.4$ billion (broken down as $€ 5.1$ billion for revenue and $€ 3.3$ billion for capital expenditure). This figure represented an increase of 14 per cent on 2018's budget. Regarding the sources of income, their contribution to the 2019 budget changed slightly from the previous year. Income from government grants/subsidies increased by 3 per cent; however, income from goods/services, commercial rates and Local Property Tax (LPT) each decreased by 1 per cent. The LPT, the most publicly prominent of these, was expected to make an allocation (post variation) of $€ 503$ million for 2019 (Department of Housing, Planning and Local Government, 2019c).

The thorny matter of the LPT revaluation continues to be deliberated by government. In April the Department of Finance published another LPT review. Completed by an interdepartmental review group, it considered the impact of house price developments on LPT liabilities. Key recommendations included the revaluation to ideally take place on 1 November 2019 and for valuations to be reviewed every four years. Despite this, the Minister for Finance, 
Paschal Donohoe, TD, decided to defer the revaluation until November 2020 to allow the matter to be considered by the Oireachtas Budgetary Oversight Committee. Needless to say, Donohoe's decision generated much political and press commentary.

When setting the LPT for 2020, the newly elected councils made substantially more variations than in previous years. In 2018 five local authorities varied their rate upwards; the corresponding figure for 2019 was nineteen. A further eight councils voted to keep their LPT at the base rate. In keeping with their track record of recent years, Dublin's four local authorities varied the LPT rate downwards.

In July a timely and modernising piece of legislation, the Local Government Rates and Other Matters Act, 2019, became law. Commercial rates, in broad terms, contribute one-third of all income $(€ 1.5$ billion in 2019) to local government. With the primary legislation for Ireland's system of commercial rates dating back to the early Victorian period, an overhaul was due. Among the Act's reforming provisions included the establishment of a property database, new obligations on owners and occupiers of relevant properties to provide necessary information, and extra powers for local authorities to apply interest to unpaid rates and set minimum rates for unoccupied properties.

\section{Efficiency and performance}

In September NOAC issued its Performance Indicator Report for 2018. Based on LGMA data and validation visits, this annual review has become a valuable component of the performance measurement framework for local government. This being the fifth such report, there is now a sizeable body of data to enable an analysis of performance change over time. NOAC's trend analysis, contained in Part Four, is very insightful. For instance, percentage improvements were observed in households availing of a three-bin service and the collection of commercial rates. Against this, however, shortcomings were identified in areas such as adult homelessness and working days lost to certified leave. For their report on 2018, NOAC added two new indicators for new waste/environment and ICT expenditure.

Ireland's strong economy is reflected in some of the figures - higher levels of new building activity, and better resourcing for local government. But despite an increased employee headcount across the sector (up by 3.39 per cent to 28,308 FTE in 2018), NOAC added a note of warning in respect of a skills gap owing to staff movement and 
retirement. In 2018 the average expenditure per capita by local authorities was $€ 978.91$, an increase from $€ 897.89$ in 2017 and $€ 842.00$ in 2016 . With public spending on the rise, compliance with systems of financial accountability and performance is more important than ever.

A further annual NOAC report (2019b), their Local Authority Quality Assurance Report, was issued in December. As part of the Public Spending Code's requirements, local authorities prepare quality assurance reports relating to expenditure (greater than $€ 0.5$ million) on projects and programmes. In turn, these are submitted to NOAC for review. NOAC's composite report provides yet more assurance of local government's broad compliance with governance principles.

\section{Other developments}

It was a year of great change for local government in Cork. In January the enactment of the Local Government Act, 2019, provided for a boundary reconfiguration between Cork City Council and Cork County Council. From 31 May the city's administrative area expanded fivefold. With this boundary alteration, over 400 services for some 85,000 citizens transferred to the city council. In addition, over 130 county council staff moved across to the city. However, the number of elected members for each council remained the same. The last extension of Cork City's administrative area took place in 1965, with much debate on further boundary alterations since then. But, for the foreseeable future, this latest chapter on the city's boundary question has closed.

Chambers Ireland's annual celebration of excellence is a wellestablished fixture in the local authority calendar. Their sixteenth excellence awards were held in November and once again showcased the best of local government. The impressive list of winners covered a diverse range of categories - from Fingal County Council's 'Our Balbriggan' initiative to Tipperary County Council's 'Sign of the Times' project and Limerick's 'Watch House Cross Community Library Autism Friendly Resource'.

The government signed the $€ 3$ billion contract for the National Broadband Plan in November. As part of its rollout, local broadband officers will continue their work with National Broadband Ireland in the delivery of a high-speed service at connection points across the country. 
Also in November, boiled water notices were issued for parts of Dublin, Kildare and Meath. This affected some 600,000 people supplied by the Leixlip water treatment plant. Such incidents bring the matter of underinvestment in water infrastructure into focus.

Finally, a significant investment in transport was announced at the end of the year. To support Project Ireland 2040, over $€ 450$ million in Exchequer funding was pledged to enable local authorities to invest in the country's national road network.

\section{Conclusion}

And so another year, and decade, has passed for local government. The sector was in a better financial position at the end of the decade than at the start. Back in the dark days of 2010, with dire public finances, the Local Government Efficiency Review Group began its cost reduction agenda. But retrenchment is over, and local government has moved into a growth phase. Challenges for the sector remain and 2019 witnessed developments aimed at addressing some of these.

Ireland's projected population growth - an extra 1 million people by 2040 - necessitates a truly strategic approach to planning. The country cannot repeat past mistakes. The OPR will thus bring expert scrutiny to local government's many development plans. Housing affordability, for low- and middle-income households, is a deepening concern. Extra support was allocated to help local authorities deliver affordable housing schemes. The task of maintaining sustainable economic growth is another national priority. To this end, policymakers expect the LEOs to redouble their efforts at supporting indigenous business owners and entrepreneurs. The Climate Action Plan was a pivotal report in 2019. Decarbonising Ireland's growing economy will be a difficult balancing act; the local authorities were given a key role in this transition. Despite a strong economy, levels of poverty and deprivation are high. The community development strategy and review of the LCDCs will help revitalise efforts at tackling social exclusion and inequality. 


\section{References}

County and City Management Association and the Local Government Management Agency. (2019). Tourism is everyone's business: Local authorities' role in tourism development. Retrieved from https://www. lgma.ie/en/publications/local-authority-sector-reports/tourism-is-everyones-business-local-authorities-role-in-tourism-development-2014-2018.pdf [3 January 2020].

Department of Finance. (2019). Review of local property tax: The report of the interdepartmental group - March 2019. Retrieved from https://www.gov.ie/en/publication/1e5c76-review-of-local-property-tax/ [2 January 2020].

Department of Housing, Planning and Local Government. (2019a). Homelessness report November 2019. Retrieved from https:// www.housing.gov.ie/housing/homelessness/other/homelessness-data [10 January 2020].

Department of Housing, Planning and Local Government. (2019b). Housing options for our ageing population policy statement. Retrieved from https://www.gov.ie/en/publication/ea33c1-housing-options-for-our-ageingpopulation-policy-statement/? referrer $=/$ wp-content/uploads/2019/02/ housingoptionsforanageingpopulationeng_web_compressed.pdf/ [10 January 2020].

Department of Housing, Planning and Local Government. (2019c). Local authority budget 2019. Retrieved from https://www.housing.gov.ie/localgovernment/administration/finance/local-authority-budget-2019 [2 January 2020].

Department of Housing, Planning and Local Government. (2019d). Marine planning policy statement. Retrieved from https:/www.housing.gov.ie/sites/ default/files/publications/files/marine_planning_policy_statement.pdf [16 December 2019].

Department of Housing, Planning and Local Government. (2019e). Social housing statistics. Retrieved from https://www.housing.gov.ie/housing/ social-housing/social-and-affordble/overall-social-housing-provision [10 January 2020].

Department of Housing, Planning and Local Government. (2019f). Traveller accommodation expert review. Retrieved from https://www.housing.gov.ie/ housing/rebuilding-ireland/report-expert-review-group-travelleraccommodation-july-2019 [10 January 2020].

Department of Public Expenditure and Reform. (2019). Spending review 2019: Analysis of social housing acquisitions. Retrieved from https://www.gov.ie/en/collection/5915ad-spending-review/ [6 January 2020].

Department of Rural and Community Development. (2019). Sustainable, inclusive and empowered communities. A five-year strategy to support the community and voluntary sector in Ireland 2019-2024. Retrieved from 
https://www.gov.ie/en/publication/d8fa3a-sustainable-inclusive-andempowered-communities-a-five-year-strategy/\#nav_menu [17 December 2019].

Government of Ireland. (2019a). Climate action plan 2019: To tackle climate breakdown. Retrieved from https://www.dccae.gov.ie/en-ie/climateaction/publications/Pages/Climate-Action-Plan.aspx [3 January 2020].

Government of Ireland. (2019b). Future jobs Ireland 2019: Preparing now for tomorrow's economy. Retrieved from https://dbei.gov.ie/en/Publications/ Publication-files/Future-Jobs-Ireland-2019.pdf [2 January 2020].

Housing Agency. (2019). Summary of social housing assessments 2019. Retrieved from https://www.housing.gov.ie/sites/default/files/publications/ files/sha_summary_2019_dec_2019_web_1.pdf [10 January 2019].

Irish Government Economic and Evaluation Service. (2019). Spending review 2019: Analysis of social housing acquisitions. Retrieved from https://www.gov.ie/en/collection/5915ad-spending-review/ [18 December 2019].

National Women's Council (2019). Women beyond the Dáil: More women in local government. Retrieved from https://www.nwci.ie/images/uploads/ NWCI_Research_Report_WEB.pdf [16 December 2019].

NOAC. (2019a). Local authority performance indicator report 2018. Retrieved from http://noac.ie/noac-reports-page/ [7 January 2020].

NOAC. (2019b). Public spending code: Local authority quality assurance report 2018. Retrieved from http://noac.ie/noac-reports-page/ [7 January 2020].

OECD. (2019). SME and entrepreneurship policy in Ireland. Retrieved from https://www.oecd.org/publications/sme-and-entrepreneurship-policy-inireland-e726f46d-en.htm [16 December 2019].

Ó'Riordáin, S. (2019). Are we there yet? Local Authority Times, 22 (1 \& 2), $1-7$.

Quinlivan, A. (2019, October). The 2019 local elections in the Republic of Ireland. Irish Political Studies.

Shannon, L. (2019). Directly-elected mayor plebiscites. Local Authority Times, 22 ( $1 \& 2), 7$. 